\title{
Taxonomic Validity of Pseudomonas denitrificans (Christensen) Bergey et al. Request for an Opinion
}

\author{
M. DOUDOROFF, R. CONTOPOULOU, R. KUNISAWA, and N. J. PALLERONI ${ }^{1}$ \\ Department of Bacteriology and Immunology, University of California, Berkeley, California 94720
}

\begin{abstract}
Eighteen strains of gram-negative, aerobic, denitrifying bacteria that are either presently classified as Pseudomonas denitrificans or that might conform to the species description have been examined in some detail. On the basis of phenotypic characterization and of limited deoxyribonucleic acid and ribosomal ribonucleic acid homology studies, they appear to belong to several species and to at least two genera. Some of the strains are described without assigning them new specific names. It is recommended that the name Pseudomonas denitrificans be abandoned as a nomen ambiguum.
\end{abstract}

Pseudomonas denitrificans was named by Bergey et al. (2), who attributed the specific epithet to Christensen (3). Christensen had applied the name Bacillus denitrificans fluorescens (not validly published) to two organisms, designated as $\mathrm{A}$ and $\mathrm{B}$, which differed from each other in minor respects but both of which were characterized by their ability to denitrify, their inability to liquefy gelatin and, as implied in the name, by the production of soluble fluorescent pigment(s). In the past 20 years, several biochemical studies have been carried out with strains identified as $P$. denitrificans and deposited as such in different culture collections. Because we have rarely encountered strains of Pseudomonas conforming to the description by Bergey et al. of Pseudomonas denitrificans (2) and because we had reason to suspect that different workers have studied different species under the same name, we examined a number of strains from our own and from other collections. We present here our arguments for abandoning the specific name $P$. denitrificans to avoid further confusion in the literature. Two strains received as $P$. denitrificans are described in some detail and other strains are partially described, but no new specific names are proposed.

\section{MATERIALS AND METHODS}

Bacterial strains. The strains used in the present study are designated as follows. Those strains described previously by us are named and numbered as

\footnotetext{
${ }^{1}$ Present address: Hoffman-La Roche, Research Division, Nutley, N.J. 07110.
}

in the earlier studies $(16,18)$ in which their sources are listed. All strains obtained subsequently from other collections are named and numbered as received by us. The prefix PJ is common to all strains of Jessen, whose assignment of these strains to his groups and biotypes is included in the listing (9). These strains were received from $H$. Lautrop. Where possible, type-culture collection numbers are included in the listing.

P. denitrificans NCIB 10465 (ATCC 19244; NCTC 1656). Strain proposed by Lysenko as neotype of the species (12).

P. denitrificans NCIB 9496 (ATCC 13867). Isolated by Sachs and Barker (17) and later studied by Delwiche (6).

\section{$P$. denitrificans NCIB 8376.}

$P$. denitrificans "Iwasaki" strain, isolated and studied by Iwasaki and Mori (8) and received from them.

$P$. denitrificans "Merck" strain. This strain was isolated by Demain et al. (7) and is in the Merck, Sharp and Dohme Laboratories collection. It was not available to us, but was kindly examined for some characters by J. Birnbaum.

$P$. denitrificans $62 \mathrm{FC}$ (ATCC 17688) received from M. Véron under this designation and listed by us as strain 322 of the "unclassified fluorescent pseudomonads" (see Tables 34 and 35 of reference 18).

$P$. fluorescens (biotype C) 205 (ATCC 17572; PJ 686-biotype 49 , group IV).

P. fluorescens (biotype B) 93 (ATCC 17467).

P. fluorescens (biotype B) 407 (ATCC 17822).

Other strains of fluorescent pseudomonads studied by Jessen (9) and examined in our laboratories:

Strains PJ 238 and PJ 706 (both biotype 50, group IV, PJ 706 from sea water).

Strain PJ 761 (biotype 51, group IV from sea water).

Strains PJ 890 (from boring), PJ 894 (from brook), and PJ 967 (from soil) are all in Jessen's biotype 36 .

Strain PJ 976 (biotype 29, group II, from soil). 
Strains PJ 944 and PJ 979 (both isolated from the same soil sample and assigned to biotype 41).

The methods for phenotypic characterization of the strains were those used by Stanier et al. (18) and further detailed by Palleroni and Doudoroff (15). In doubtful cases, the replica plate method of nutritional characterization was confirmed by repeated subcultures in liquid media.

Deoxyribonucleic acid (DNA)-DNA hybridizations were carried out at $25 \mathrm{C}$ below the melting temperature of the immobilized reference DNA as previously described (1).

Ribosomal ribonucleic acid (rRNA)-DNA hybridizations were performed as described previously (16).

\section{RESULTS}

The "Iwasaki" strain has peritrichous cells, produces no soluble pigments, does not liquefy gelatin or ferment carbohydrates, causes vigorous denitrification, and accumulates poly- $\beta$ hydroxybutyrate as a reserve material. Its nutritional spectrum, which will not be detailed here, has been compared with those of Alcaligenes faecalis and Alcaligenes eutrophus (5), neither of which it resembles closely.

The "Merck" strain, which was not available to us for study, was reported by J. Birnbaum of Merck, Sharp and Dohme Research Laboratories to denitrify and to accumulate poly- $\beta$ hydroxybutyrate but to produce neither soluble pigments nor gelatin hydrolysis (personal communication). Unfortunately, the mode of flagellar insertion was not determined.

Strain $62 \mathrm{FC}$ has already been described by us as strain 322 and placed among the "unclassified" fluorescent pseudomonads (18). It has cells with a number of flagella at the poles, produces soluble fluorescent pigment(s), and does not hydrolyze gelatin or accumulate poly- $\beta$-hydroxybutyrate. All attempts, however, to cause it to denitrify or even to grow reasonably well under anaerobic conditions in media with nitrate met with failure. The guanine plus cytosine $(\mathrm{G}+\mathrm{C})$ content of the DNA is about $62 \mathrm{~mol} \%$ (by buoyant density).

Strain NCIB 8376 possesses cells with a number of polar flagella, produces soluble fluorescent pigment(s), denitrifies, and does not ferment carbohydrates, accumulate poly- $\beta$ hydroxybutyrate, or produce levan from sucrose. It hydrolyzes gelatin. In the above respects and in its nutritional spectrum, which we have characterized extensively, it can be readily recognized as a member of $P$. fluorescens biotype C (1966).

The cells of strains NCIB 10465 and NCIB 9496 bear single, polar flagella. Neither strain produces any pigments on media $\mathrm{A}$ and $\mathrm{B}$ of
King et al. (10), accumulates poly- $\beta$-hydroxybutyrate, hydrolyzes gelatin, forms levan on complex media with sucrose, or ferments carbohydrates (in the strict sense of fermentation). They do not grow at $4 \mathrm{C}$ or at $40 \mathrm{C}$. Both strains can grow aerobically in mineral media with ammonium salts as the sole source of nitrogen and with single sources of carbon, and can denitrify under anaerobic conditions. Strain NCIB 10465, however, grows much more slowly than NCIB 9496 and denitrifies much less vigorously. The addition of casein hydrolysate greatly increases the rate of growth of NCIB 10465. DL-Lactate is the best carbon source for denitrification by both strains.

Carbon sources used by both strains for aerobic growth are acetate, butyrate, isobutyrate, valerate, caproate, caprate, succinate, fumarate, azelate, sebacate, lactate, pyruvate, D-malate, DL- $\beta$-hydroxybutyrate, citrate, aconitate, levulinate, itaconate, mesaconate, benzoate, $\alpha$-L-alanine, $\alpha$-D-alanine, $\beta$-alanine, $\gamma$-aminobutyrate, proline, and betaine.

The following compounds are used by neither strain: $n$-dodecane, $n$-hexadecane, isopropanol, isobutanol, ethylene glycol, propylene glycol, 2,3-butylene glycol, glycerol, erythritol, mannitol, sorbitol, meso-inositol, adonitol, ribose, xylose, L-arabinose, mannose, galactose, L-rhamnose, D-fucose, trehalose, maltose, lactose, cellobiose, starch, inulin, salicin, 2-ketogluconate, saccharate, mucate, formate, malonate, glycollate, glycerate, D-, L-, and meso-tartrate, poly- $\beta$-hydroxybutyrate, citraconate, hydroxymethylglutarate, Dmandelate, ortho- and meta-hydroxybenzoate, phthalate, phenylacetate, naphthalene, phenol, quinate, glycine, L-serine, L-threonine, norleucine, valine, citrulline, $\alpha$-aminobutyrate, $L$ phenylalanine, L-tryptophan, D-tryptophan, Lkynurenine, kynurenate, anthranilate, histamine, butylamine, creatine, acetamide, nicotinate, and trigonelline.

The compounds used well by strain NCIB 9496 but not used by NCIB 10465 are: geraniol, D-arabinose, glucose, fructose, gluconate, propionate, isovalerate, heptonoate, caprylate, pelargonate, glutarate, adipate, pimelate, $\alpha$-ketoglutarate, benzoylformate, para-hydroxybenzoate, leucine, isoleucine, aspartate, asparagine, glutamate, lysine, arginine, ornithine, $\alpha$ - and $\delta$-aminovalerate, histidine, putrescine, spermine, $\alpha$-amylamine, and sarcosine.

Sucrose, suberate, and pantothenate are good carbon sources for strain NCIB 10465, which can also use ethanol, propanol, butanol, Lmandelate, and hippurate poorly. None of the above compounds is used by NCIB 9496. 
The $\mathrm{G}+\mathrm{C}$ content of the DNA (by buoyant density) was found to be about $62.8 \mathrm{~mol} \%$ for strain NCIB 10465 and $66.3 \mathrm{~mol} \%$ for NCIB 9496. Results of in vitro DNA-DNA and DNA-rRNA hybridization experiments are shown in Table 1. Selected strains belonging to different DNA and rRNA homology groups (16) of pseudomonads (including Xanthomonas campestris) were used in the studies.

Twelve strains of fluorescent pseudomonads that we have examined conformed to our interpretation of the organism designated as $P$. denitrificans by Bergey et al. (2) in the pigmentation, ability to denitrify, and inability to hydrolyze gelatin. Three of these strains had been included in our previous studies (18), and one of them was used in some DNA hybridization experiments (14). We had assigned strains 93 and 407 to $P$. fluorescens biotype B and strain 205 to biotype $C$ of the same species. The absence of gelatin hydrolysis was not considered to be of sufficient importance to bar them from these assignments in view of other specific and varietal characters possessed by them. Nine other strains from Jessen's collection were subsequently analyzed by us. Two of these, PJ 706 and PJ 238, could best be classified as slightly atypical strains of $P$.

TABLE 1. DNA and rRNA homologies of strains NCIB 1406 and NCIB 9496 with other Pseudomonas species

\begin{tabular}{|c|c|c|c|c|c|c|}
\hline \multirow[b]{3}{*}{$\begin{array}{l}\text { Species, biotype, and } \\
\text { strain no. }\end{array}$} & \multirow[b]{3}{*}{$\begin{array}{c}\text { DNA } \\
(\% \mathrm{G}+\mathrm{C})\end{array}$} & \multicolumn{4}{|c|}{ Competition $^{a}(\%)$} & \multirow{3}{*}{$\begin{array}{c}\text { IRNA } \\
\text { homology } \\
\text { group (16) }\end{array}$} \\
\hline & & \multicolumn{2}{|c|}{ DNA-DNA } & \multicolumn{2}{|c|}{ DNA-rRNA } & \\
\hline & & $\begin{array}{l}\text { NCIB } \\
10465\end{array}$ & $\begin{array}{l}\text { NCIB } \\
9496\end{array}$ & $\begin{array}{l}\text { NCIB } \\
10465\end{array}$ & $\begin{array}{l}\text { NCIB } \\
9496\end{array}$ & \\
\hline NCIB 10465 & 63 & $(100)$ & 0 & $(100)$ & & \\
\hline NCIB 9496 & 66 & 0 & $(100)$ & & $(100)$ & \\
\hline$P$. aeruginosa 131 & 67 & 4 & 31 & 84 & 86 & \\
\hline P. fluorescens A192 & $61^{b}$ & 20 & 18 & & & \\
\hline A1 84 & $61^{b}$ & 36 & 28 & & & \\
\hline B93 & $61^{b}$ & 0 & 2 & & & \\
\hline B400 & 61 & & 13 & & & \\
\hline B413 & $61^{b}$ & 17 & 10 & & & \\
\hline C18 & 61 & 0 & 0 & & & \\
\hline $\mathrm{D} 390^{c}$ & 64 & 6 & 27 & 88 & 84 & I \\
\hline E38 & 64 & 0 & 8 & & & \\
\hline P. putida A90 & 63 & 4 & 13 & & & \\
\hline B53 & 61 & 0 & 0 & & & \\
\hline P. phaseolicola 760 & $59^{b}$ & 0 & 0 & & & \\
\hline P. cichorii 136 & $58^{b}$ & 0 & 0 & & & \\
\hline P. stutzeri 220 & 62 & 0 & 0 & & & \\
\hline P. mendocina $\mathrm{CH} 120$ & 64 & 9 & 10 & & & \\
\hline P. alcaligenes 142 & 66 & 5 & 13 & & & \\
\hline P. pseudoalcaligenes 63 & 63 & 0 & 0 & & & \\
\hline P. cepacia 382 & 68 & 0 & 0 & 49 & 54 & \\
\hline P. caryophylli bc1 13 & 66 & 0 & & & & II \\
\hline P. pseudomallei 163 & 69 & 0 & & & & \\
\hline P. pickettii K300 & 64 & 0 & 0 & & & \\
\hline P. acidovorans 14 & 67 & 0 & 0 & 38 & 36 & \\
\hline P. testosteroni 78 & 62 & 0 & 0 & & & III \\
\hline P. diminuta 501 & 67 & 0 & 6 & & & IV \\
\hline P. maltophilia 67 & 67 & 0 & 0 & 50 & 51 & V \\
\hline$X$. campestris XC-1 & $68^{b}$ & & & 60 & 47 & \\
\hline
\end{tabular}

${ }^{a}$ DNA-DNA hybridizations were carried out with DNA from NCIB 10465 and NCIB 9496 as reference DNA at $70.5 \mathrm{C}$ and $72.2 \mathrm{C}$, respectively. DNA-rRNA hybridizations were performed at $65 \mathrm{C}$ with immobilized DNA and reference rRNA of the species listed and with competitor rRNA from strains NCIB 10465 and NCIB 9496.

${ }^{b}$ DNA composition determined with related strains.

${ }^{c}$ Closely related strain 31 was used as reference in DNA-rRNA hybridizations. 
TABLE 2. Properties of some fluorescent denitrifying Pseudomonas strains that do not hydrolyze gelatin

\begin{tabular}{|c|c|c|c|c|c|c|c|c|c|c|c|c|c|c|c|}
\hline $\begin{array}{l}\text { Determin - } \\
\text { ation }\end{array}$ & 205 & $\begin{array}{c}\text { PJ } \\
238\end{array}$ & $\begin{array}{c}\text { PJ } \\
706\end{array}$ & $\begin{array}{c}\text { PJ } \\
761\end{array}$ & $\begin{array}{c}\text { PJ } \\
967\end{array}$ & $\begin{array}{c}\text { PJ } \\
890\end{array}$ & $\begin{array}{c}\text { PJ } \\
894\end{array}$ & 93 & 407 & $\begin{array}{c}\text { PJ } \\
976\end{array}$ & $\begin{array}{c}\text { PJ } \\
944\end{array}$ & \begin{tabular}{|c||} 
PJ \\
979
\end{tabular} & $\begin{array}{l}\text { P. fluores- } \\
\text { cens } \mathrm{C}^{a}\end{array}$ & $\begin{array}{l}\text { P. fluores- } \\
\text { cens } \mathrm{B}^{a}\end{array}$ & $\begin{array}{l}\text { P. pu- } \\
\text { tida } \mathrm{B}^{a}\end{array}$ \\
\hline $\begin{array}{l}\text { Levan from } \\
\text { sucrose }\end{array}$ & - & - & - & - & - & - & - & + & + & - & - & - & - & + & - \\
\hline $\begin{array}{l}\text { Egg yolk } \\
\text { reaction }\end{array}$ & \pm & + & + & + & - & - & - & - & - & - & - & - & + & V & - \\
\hline Growth with: & & & & & & & & & & & & & & & \\
\hline Trehalose & + & + & + & + & + & + & + & + & + & + & + & + & + & + & - \\
\hline Inositol & + & + & + & + & + & + & + & + & + & - & - & - & + & + & - \\
\hline D-Xylose & - & - & - & - & - & + & + & \pm & + & + & - & - & - & $(+)$ & V \\
\hline L-Arabinose & - & - & + & + & + & + & + & + & + & + & + & + & - & $(+)$ & $(+)$ \\
\hline Saccharate & - & \pm & - & + & + & + & + & + & + & + & + & + & - & $(+)$ & $(+)$ \\
\hline Sorbitol & - & - & - & + & + & + & + & + & + & - & + & + & $(-)$ & + & $(+)$ \\
\hline Erythritol & + & + & + & + & - & - & - & - & - & - & - & - & + & $\mathrm{V}$ & - \\
\hline $\begin{array}{l}\text { Hydroxymeth- } \\
\text { ylglutarate }\end{array}$ & - & - & - & - & - & - & + & - & + & - & - & - & - & $(+)$ & - \\
\hline Trigonelline & - & - & - & - & + & - & - & + & + & + & + & + & - & $(+)$ & + \\
\hline Pantothenate & + & - & + & + & - & - & - & - & - & - & - & - & $(+)$ & - & - \\
\hline Adipate & + & + & + & - & - & - & - & - & - & - & - & - & $\mathrm{V}$ & - & $(-)$ \\
\hline Sebacate & + & + & + & - & - & - & - & - & - & - & - & - & V & - & $(-)$ \\
\hline Histamine & - & - & - & - & - & + & - & - & - & + & + & + & - & $(-)$ & $(+)$ \\
\hline Benzylamine & - & - & - & - & - & + & \pm & - & - & + & \pm & + & $(-)$ & - & + \\
\hline Glycine & - & - & - & - & - & - & - & - & - & \pm & + & + & - & - & + \\
\hline Hippurate & - & - & - & - & - & - & - & - & - & - & + & \pm & $(-)$ & - & + \\
\hline Creatine & - & - & - & - & - & - & - & - & - & + & + & + & $(-)$ & - & + \\
\hline
\end{tabular}

${ }^{a}$ Some properties of related fluorescent Pseudomonas biotypes (typical $P$. fluorescens liquefy gelatin, and biotypes B and C denitrify, whereas $P$. putida does not hydrolyze gelatin or denitrify). The following symbols are used for group characterization: + or -, universally or almost universally positive and negative characters of the group; $(+)$ or $(-)$, generally but not universally positive and negative for the group; V, variable characters that may or may not be useful in recognizing strain affinities.

fluorescens biotype $\mathrm{C}$. Their placement in this group was supported by their ability to utilize higher decarboxylic acids (e.g., adipate, sebacate), which are used by many strains of this biotype but by almost no fluorescent pseudomonads other than $P$. aeruginosa. Four strains (PJ 761, PJ 967, PJ 890, and PJ 894) had some characteristics of both biotypes $\mathrm{B}$ and $\mathrm{C}$ of $P$. fluorescens. Three strains (PJ 976, PJ 944, and PJ 979) could not be placed in any biotype previously circumscribed by us, since they have some characteristics of both $P$. fluorescens and $P$. putida. They resemble $P$. fluorescens in their ability to denitrify and to use trehalose, but resemble $P$. putida in their inability to liquefy gelatin or to use inositol and in their growth with a number of substrates rarely utilized by $P$. fluorescens (see Table 12 of reference 18). It should be noted that strains PJ 944 and PJ 979 were isolated from the same sample and may represent the same strain. They are the only representatives assigned by Jessen to his biotype 41.

Some selected differential characteristics of the 12 strains of fluorescent pseudomonads discussed above are listed in Table 2, together with the corresponding properties of $P$. fluorescens biotypes $\mathrm{B}$ and $\mathrm{C}$ and of $P$. putida biotype $\mathrm{B}$, which is the most closely related $P$. putida biotype.

\section{DISCUSSION}

The present confusion in the bacteriological and biochemical literature, as well as in culture collections, regarding the identity of Pseudomonas denitrificans may in part be attributed to the attempt by Bergey et al. to preserve Christensen's specific epithet in the assignment of the species to the genus Pseudomonas. Bergey et al. (2) followed Christensen's description (3) of Bacillus denitrificans fluorescens, for which the production of soluble fluorescent pigment, the ability to denitrify, and the inability to liquefy gelatin are the principal distinguishing characters described or implied. Although motility was attributed to the species by Christensen, the mode of flagellar insertion was not described. 
In the first edition of Bergey's Manual (2), where the name $P$. denitrificans first appears, the genus Pseudomonas is characterized by the production of green, blue, or yellowish-green, water-soluble pigments that diffuse into the medium and by cells which, when motile, are monotrichous or peritrichous. The species is described as being "peritrichous (?)." In the second (1925), third (1930), and fourth (1934) editions, the generic description is repeated, but the question mark disappears after "peritrichous" in the species description. In the fifth edition (1939), the generic description for the first time specifies polar flagellation (some nonmotile species are included, as in previous editions). $P$. denitrificans is described as being motile and appears in the determinative key in a section with other species for which the mode of flagellar insertion has not been reported. In the sixth edition (1948), polar flagellation and the usual production of bluish-green or yellowish-green diffusible pigments are listed as generic characters, whereas in the seventh edition (1957) many more colors are listed. The species description appears unchanged in the last three editions, but in the last edition $P$. denitrificans is listed in the determinative key among species for which soluble pigments are "not produced or not reported."

In view of the changes in the generic and specific descriptions mentioned above, it is not surprising that peritrichous and polarly flagellated, fluorescent and nonfluorescent organisms have been identified as $P$. denitrificans by different workers.

The Iwasaki strain of "P. denitrificans," which we have examined, has peritrichous cells and does not produce soluble pigments or hydrolyze gelatin. According to our proposal for the circumscription of the genus Alcaligenes (4), it should be regarded as a representative of an apparently unnamed species of this genus. This strain differs in at least 15 characters from the non-denitrifying species $A$. faecalis (unpublished data) and from the denitrifying hydrogen bacterium $A$. eutrophus. We have not compared it with the illegitimately named $A$. denitrificans Leifson and Hugh (11), nor have we examined any strains of $A$. denitrificans Monias (13); indeed, original strains of the latter organism may not even be available. Our meager information about the Demain strain indicates that it does not conform to Christensen's specific description of Bacillus denitrificans fluorescens. Without knowledge of its mode of flagellation, we cannot say whether it belongs to the genus Pseudomonas or Alcaligenes.

In our experience with several hundred strains of Pseudomonas, we have encountered only a few strains that denitrify, produce fluorescent pigment(s), and do not hydrolyze gelatin. Some strains of $P$. caryophylli do produce a greenish-yellow, soluble pigment under some conditions and in the two other respects conform to the description of $P$. denitrificans, but the pigment is not fluorescent in ultraviolet light. In any case, $P$. caryophylli is an unlikely candidate for synonymy with $P$. denitrificans because of its apparently specialized habitat as a phytopathogen.

Of the fluorescent, denitrifying, gelatinasenegative strains that we have encountered, some had already been placed in $P$. fluorescens biotype $\mathrm{B}$ and $\mathrm{C}$, and most others can be regarded as somewhat aberrant representatives of the same species. Although the loss of ability to hydrolyze gelatin has not been observed in our own cultures, there is no reason to believe that it does not occur in nature or in culture collections, and may, indeed, be the result of a single mutational event. The fact that some of the strains do not entirely conform to our previous descriptions of different $P$. fluorescens biotypes (18) cannot be used as an argument for creating new biotypes or species, because it should be recognized that our approach to classification has been a very coarse one, with an emphasis on "lumping" rather than on "splitting" taxa. No pretense is made that the species and biotypes as previously circumscribed do not include a number of what may be eventually recognized as "true" bacterial species. The three strains PJ 976, PJ 944, and PJ 979, the last two of which may represent separate isolates of the same strain, are the only ones that may deserve a separate specific epithet, but we are not prepared to propose one until additional similar strains are isolated. The affinity of these strains to both $P$. fluorescens and $P$. putida (as defined by us) may simply mean that our distinction between the two species was too rigidly conceived. This was already suggested by our DNA homology and immunological studies, which indicate that $P$. putida biotype B may include representatives of $P$. fluorescens (15). In any case, we see no reason for resurrecting the epithet denitrificans for these strains, because they are no more identifiable with this nomen species than are any of the other strains studied.

The strains NCIB 10465 and NCIB 9496, neither of which produces soluble pigments, are clearly members of two distinct Pseudomonas species that have not been previously studied by us. Although both are monotrichous and do not accumulate poly- $\beta$-hydroxybutyrate, they differ from each other in at least 40 phenotypic characters, including overall DNA composition. 
TABLE 3. Some phenotypic characters distinguishing strains NCIB 10465 and NCIB 9496 from other well-characterized denitrifying species of Pseudomonas ${ }^{a}$

\begin{tabular}{|c|c|c|}
\hline Species & NCIB 10469 & NCIB 9496 \\
\hline $\begin{array}{l}P . \text { aeruginosa } \\
P . \text { fluorescens }^{b} \\
P . \text { stutzeri }^{c} \\
P . \text { mendocina } \\
P . \text { pseudomallei } \\
P . \text { caryophylli } \\
P . \text { pickettii } \\
P . \text { solanacearum }\end{array}$ & $\begin{array}{l}c-; e-; g-; i-; j-; l-; p-; r- \\
a+; d-; e-; i-; j-; l-; p- \\
c-; f-; h-; j-; q+ \\
c-; g-; j-; k-; l-; m-; o- \\
a+; b-; c-; e-; f-; i-; j-; \\
\quad l-; n+; o+; p- \\
a+; b-; c-; i-; j-; k-; l-; \\
m-; n+; o+; p- \\
b-; c-; j-; k-; l-; m_{-} ; n_{+} \\
o+; q^{+} \\
b-; j-; k-; n+; o^{+} q_{+}\end{array}$ & $\begin{array}{l}c-; e-; i-; l-; r- \\
a+; d-; e-; g+; i-; l- \\
c-; f-; g-; h-; p+; q^{+} \\
c-; k-; l-; m- \\
a+; b-; e-; f-; g+; i-; l-; \\
\quad n+; o+ \\
a+; b-; c-; g+; i-; k-; l-; \\
\quad m-; n+; o+ \\
b-; c-; g^{+} ; k-; l-; m-; n+; \\
\quad o_{+}^{+} p+; q^{+} \\
b-; g+; k-; n+; o+; p+; q^{+}\end{array}$ \\
\hline
\end{tabular}

$a_{+}$or - refers to positive or negative character of the strain described as compared with all or almost all strains that we have examined and assigned to the species listed. The differential characters are listed below (characters $g$ through $r$ refer to ability to use various compounds as sole sources of carbon for aerobic growth); $a$, monotrichous cells; $b$, accumulation of poly- $\beta$-hydroxybutyrate granules as reserve material; $c$, grow th at $40 \mathrm{C} ; d$, growth at $4 \mathrm{C} ; e$, hydrolysis of gelatin; $f$, hydrolysis of starch; $g$, geraniol; $h$, ethylene glycol; $i$, mannitol; $j$, glucose; $k$, saccharate; $l$, malonate; $m$, glycollate; $n$, itaconate; $o$, mesaconate; $p$, arginine; $q$, betaine; $r$, acetamide.

$b$ Biotypes $\mathrm{B}$ and $\mathrm{C}$ and $P$. chlororaphis ( $P$. fluorescens biotype D).

$\boldsymbol{c}$ Includes $P$. stanieri.

TABLE 4. Summary of taxonomic status of strains designated as $P$. denitrificans and of other possible candidates for the specific assignment

\begin{tabular}{|c|c|}
\hline Strains & Description \\
\hline \multicolumn{2}{|c|}{$\begin{array}{l}\text { Strains not conforming to our interpretation } \\
\text { of the species description }\end{array}$} \\
\hline "Iwasaki" & $\begin{array}{l}\text { Peritrichous cells; probably unnamed species } \\
\text { of Alcaligenes }\end{array}$ \\
\hline "Merck" & No pigments; may be Pseudomonas or Alcaligenes \\
\hline NCIB 10465 & No pigments; unnamed Pseudomonas species \\
\hline NCIB 9496 & $\begin{array}{l}\text { No pigments; Pseudomonas species distinct from } \\
\text { NCIB } 10465\end{array}$ \\
\hline NCIB 8376 & Liquefies gelatin; $P$. fluorescens biotype C (18) \\
\hline $62 \mathrm{FC}$ & $\begin{array}{l}\text { No denitrification; unclassified fluorescent } \\
\text { pseudomonad (18) }\end{array}$ \\
\hline \multicolumn{2}{|c|}{$\begin{array}{l}\text { Strains not received as } P \text {. denitrificans } \\
\text { conforming to our interpretation of the } \\
\text { species description }\end{array}$} \\
\hline $93 ; 407$ & Atypical $P$. fluorescens biotype B (18) \\
\hline 205; PJ 706; PJ 238 & Atypical P. fluorescens biotype C \\
\hline PJ 761; PJ 967; PJ 890; PJ 894 & Atypical $P$. fluorescens near biotypes $\mathrm{B}$ and $\mathrm{C}$ \\
\hline PJ 976; PJ 944; PJ 979 & $\begin{array}{l}\text { Representative of one or two unclassified } \\
\text { Pseudomonas species with some characters of } \\
P . \text { fluorescens and of } P \text {. putida }\end{array}$ \\
\hline
\end{tabular}

No DNA homology was detected between the two strains, but significant homology was found between each of them and several species of the "P. fluorescens complex" (Table 1). That both strains are nonfluorescent members of this complex was even more convincingly shown by their high rRNA homology with $P$. aeruginosa and $P$. chlororaphis ( $P$. fluorescens biotype D), which both belong to the rRNA homology group I (16). Like $P$. mendocina, both strains show a slightly lower rRNA homology with the two fluorescent species than do the fluorescent members of the complex. Although strains NCIB 10465 and NCIB 9496 are interesting organisms, representing apparently two hitherto unnamed species, we do not believe in assigning them new specific names until more strains that resemble them are discovered or until a large 
enough body of literature dealing with either of them has accumulated to make a specific name worth establishing. We have, however, described their properties in some detail for other workers who may use them in their studies and who may find other similar strains. Table 3 gives some diagnostic, phenotypic characters that may be used to distinguish them from other denitrifying Pseudomonas species.

Table 4 summarizes our observations on the strains that we have studied and our opinion of their taxonomic position. Considering the absence of a type strain of $P$. denitrificans and the present confusion regarding the identity of existing named strains, we propose that the specific name Pseudomonas denitrificans be abandoned as a nomen ambiguum and request that the Judicial Commission of the International Committee on Systematic Bacteriology so rule.

\section{ACKNOWLEDGMENTS}

We thank Manley Mandel for determining the DNA composition of some of the strains studied and $\mathrm{J}$. Birnbaum for testing the "Merck" strain for several phenotypic characters.

These studies were supported by Public Health Service grant AI-1808 from the National Institute of Allergy and Infectious Diseases.

\section{REPRINT REQUESTS}

Address reprint requests to: Dr. M. Doudoroff, Department of Bacteriology and Immunology, University of California, Berkeley, California 94720.

\section{LITERATURE CITED}

1. Ballard, R. W., N. J. Palleroni, M. Doudoroff, R. Y. Stanier, and M. Mandel. 1970. Taxonomy of the aerobic pseudomonads: Pseudomonas cepacia, $P$. marginata, $P$. alliicola, and $P$. caryophylli. J. Gen. Microbiol. 60:199-214.

2. Bergey, D. H., F. C. Harrison, R. S. Breed, B. W. Hammer, and F. M. Huntoon (ed.). 1923. Bergey's manual of determinative bacteriology, 1 st ed. Williams and Wilkins Co., Baltimore.

3. Christensen, H. R. 1903. Zwei neue fluoreszierende Denitrifikationsbakterien. Zentralbl.
Bakteriol. Parasitenk. Infektionskr. Hyg. Abt. 2. 11:190-194.

4. Davis, D. H., M. Doudoroff, R. Y. Stanier, and M. Mandel. 1969. Proposal to reject the genus Hydrogenomonas: taxonomic implications. Int. J. Syst. Bacteriol. 19:375-390.

5. Davis, D. H., R. Y. Stanier, M. Doudoroff, and M. Mandel. 1970. Taxonomic studies on some Gram negative polarly flagellated "hydrogen bacteria" and related species. Arch. Mikrobiol. 70:1-13.

6. Delwiche, C. C. 1959. Production and utilization of nitrous oxide by Pseudomonas denitrificans. J. Bacteriol. 77:55-59.

7. Demain, A. L., H. J. Daniels, L. Schuable, and R. F. White. 1968. Specificity of the stimulatory effect of betaine on the vitamin $\mathrm{B}_{12}$ fermentation. Nature (London) 220:1324-1325.

8. Iwasaki, H., and T. Mori. 1955. Studies on denitrification. I. Nitrogen production by a strain of denitrifying bacteria using toluene blue as a hydrogen carrier. J. Biochem. (Tokyo) 42:375380 .

9. Jessen, O. 1965. Pseudomonas aeruginosa and other green fluorescent pseudomonads. A taxonomic study. Munksgaard, Copenhagen.

10. King, E. O., M. K. Ward, and D. E. Raney. 1954. Two simple media for the demonstration of pyocyanin and fluorescein. J. Lab. Clin. Med. 44:301-000.

11. Leifson, E., and R. Hugh. 1954. Alcaligenes denitrificans n. sp. J. Gen. Microbiol. 11:512-513.

12. Lysenko, O. 1961. Pseudomonas. An attempt at a general classification. J. Gen. Microbiol. 25:379. 408.

13. Monias, B. L. 1928. Classification of Bacterium alcaligenes, pyocyaneum and fluorescens. J. Infect. Dis. 43:330-334.

14. Palleroni, N. J., R. W. Ballard, E. Ralston, and M. Doudoroff. 1972. Deoxyribonucleic acid homologies among some Pseudomonas species. J. Bacteriol. 110:1-11.

15. Palleroni, N. J., and M. Doudoroff. 1972. Some properties and taxonomic subdivisions of the genus Pseudomonas. Annu. Rev. Phytopathol. 10:73-100.

16. Palleroni, N. J., R. Kunisawa, R. Contopoulou, and M. Doudoroff. 1973. Nucleic acid homologies in the genus Pseudomonas. Int. J. Syst. Bacteriol. 23:333-339.

17. Sachs, L. E., and H. A. Barker. 1952. Substrate oxidation and nitrous oxide utilization in denitrification. J. Bacteriol. 64:247-252.

18. Stanier, R. Y., N. J. Palleroni, and M. Doudoroff. 1966. The aerobic pseudomonads: a taxonomic study. J. Gen. Microbiol. 43:159-271. 